\title{
College Library Friends Groups in New York, New Jersey, and Connecticut
}

\section{Janet Butler Munch}

Friends of the Library groups are largely undocumented in the professional literature at nondoctoral-granting colleges and universities. Through a survey of Friends' activities at colleges and universities in the tristate area of New York, New Jersey, and Connecticut, this study fills a gap in knowledge about these groups.

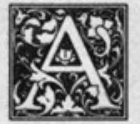

$s$ budgets strain to meet the rising costs of acquisitions, computerization, networking, specialized services, and personnel, college libraries increasingly look toward Friends of the Library groups. Support organizations operating outside the library's administrative umbrella, these groups are typically formed for the purpose of promoting the library. Additionally, Friends groups transmit the library's needs to the community and serve as a source of financial and in-kind donations that, in turn, are used to enhance library collections and services.

From 35 groups in $1937,{ }^{1}$ the number of Friends groups in the U.S. grew by 1987 to more than $2,300 .^{2}$ While Friends groups are predominantly a public library phenomenon, academic library interest is evident from the increase in the number of documented groups from 27 in $1978^{3}$ to 293 by $1985 .{ }^{4}$ Large research and university libraries have long dominated academic library involvement with Friends groups.

\section{PREVIOUS STUDIES}

The research literature on college library
Friends groups is extremely limited; much of what is known is derived from surveys. The earliest known research on academic groups is Esther H. Dixon's 1939 study, ${ }^{5}$ which identified fifty Friends groups from universities, colleges, teachers' and junior colleges, with research libraries predominating. In 1951, M. Allyn Fox surveyed 102 groups known in 1949 and, with a 68 percent response rate of sixty-nine, found that thirty-seven had active groups while thirty-two no longer existed. ${ }^{6}$ Friends groups have been known to thrive in times of poor funding and rising costs and to decline in times of plenty. By 1961, Mother M. Fabian Carney surveyed 208 Catholic colleges and universities (not including junior colleges). ${ }^{7}$ Of 146 responses, or 70 percent of the total number surveyed, she found that seventeen libraries had Friends groups, forty-eight hoped to have such a group in the future, and eighty-one neither had nor planned such a group. Four institutions with Friends groups planned to drop them, in most cases as a response to internal pressure (e.g., from development officers). In 1975, Ann Gwyn and others surveyed groups in research, public, small univer-

Janet Butler Munch is Special Collections Librarian at Herbert H. Lehman College Library, City University of New York, New York 10021. 
sity and special libraries. ${ }^{8}$ With a return of 129 out of 159 or 81 percent, colleges and universities constituted 56 percent of the Friends groups responding. The limitation of this study is that it did not differentiate between college and research universities.

The most recent surveys documenting these groups have been conducted by the Friends of Libraries U.S.A. Their 1978 and 1985 studies were nationwide and included all types of libraries: public, special, school, and academic. ${ }^{9}$ In the more recent survey, academic groups were identified as growing most rapidly.

\section{PRESENT STUDY}

The present study developed from a desire to form a Friends of the Library group at Lehman College of the City University of New York. Responsibility for planning was delegated to the special collections librarian and a task force of appointed colleagues. Seeking to learn from the experiences of other college libraries, the group conducted a literature search. Although some insights were gained, they found Friends groups in college libraries to be underdocumented. Indeed, even those vital college Friends groups known to colleagues in the local geographic area were not reported in the professional literature. In an effort to facilitate the planning process, the task force at Lehman decided to survey like colleges regarding the existence and operation of these groups. As the last published listing (1978) of the Friends of Libraries U.S.A. cited just three New York State academic groups and the 1982 Citizens Library Council directory identified only five groups, it appeared that the number of college library Friends group to survey would be small. ${ }^{10}$ The survey was therefore broadened to include the adjoining states of New Jersey and Connecticut, thus allowing for site visits or long-distance calls if needed. Colleges similar to Lehman College (i.e., offering an undergraduate and graduate program through the master's level) would have the fewest institutional variables and would yield the most comparable and therefore useful information.

\section{Methodology}

This study used an open-ended questionnaire to trace the formation of college library Friends' groups and identify their operational concerns. The survey population was compiled by cross-checking standard sources for college classification status. ${ }^{11}$ Selected were accredited colleges emphasizing baccalaureate and postbaccalaureate programs through the master's level but not including doctoral or research institutions, specialized or community colleges. Questionnaires were sent to 124 college libraries in the tristate area during summer 1987.

\section{RESULTS \\ Existence of Friends Groups}

The first and second follow-up mailings drew a total response of 103 out of 124 questionnaires ( 83 percent). Of the responding libraries, twenty-two (21.3 percent) indicated that they have Friends groups.

Of the eighty-two responding libraries that did not currently have Friends organizations, eighteen (17.4 percent) indicated that they are considering starting such a group. An additional ten college libraries responded that they had had a Friends group at one time, but that it was no longer in operation. Of these ten institutions, only three libraries indicated that they might in the future reactivate their Friends group. Reasons given for not considering reactivation were: a void in Friends leadership, lack of time, or institutional pressure to disband. Only eight of thirteen college Friends groups identified by the Friends of Libraries U.S.A. in their 1985 survey $^{12}$ and also included in this study are still in operation. Clearly, Friends groups are subject to the volatility of administrative and organizational change.

Four responding institutions with no current or past group cited the presence of an institutional (nonlibrary) Friends group. At some colleges, library Friends groups are perceived as conflicting with the college's desire for centralizing institutional fund-raising. In other institutions, library committees, informal receptions of 
faculty, and alumni support are seen as mitigating the need for a formal Friends group. Another factor that sometimes discourages the formation of a Friends group is the presence of an undergraduate college library in a university setting. In such cases, there is often one Friends group for the institutional libraries as a whole and not for the individual free-standing college libraries.

\section{Founding Dates of Friends Groups}

Among those college libraries responding, the earliest academic Friends group was founded in 1940 . However, 65.2 percent of all groups were established between 1966 and 1975 or after 1980. This clustering in formation of Friends groups is symptomatic of the stresses felt in higher education at those times. The 1960s were, for colleges, a golden age of peak enrollment and expanded program offerings. By the end of the decade, however, enrollment of the traditional eighteen-totwenty-one-year-old age group declined as higher education was eschewed as never before. By the early 1970s, colleges were closing in record numbers and retrenchment became the watchword. The weakened purchasing power of the dollar has affected colleges into the present decade and colleges are still scrambling to tap new enrollment markets. In recent decades the founding of new Friends groups has increased as if in response to the vicissitudes of these negative trends.

\section{Institutional Data}

The twenty-two libraries that have Friends groups have volume counts ranging from less than 100,000 to more than $1,000,000$. Some 78.2 percent however, have fewer than 500,000 volumes; and 26 percent hold less than 200,000 volumes. Periodical count did not seem to be a significant factor; 52.1 percent of those institutions having Friends have fewer than 2,000 titles.

Number of professional staff was another variable analyzed. Responses indicated that 65.2 percent of those institutions having Friends groups had a professional staff of less than fifteen. Responding institutions with professional staffs of from five to ten had a surprising 34.4 percent of the Friends groups. Notably, two libraries with professional staffs of five or fewer had thriving groups. A small professional staff does not, therefore, necessarily nullify the formation of a Friends group.

Additional data collected included the date when the Friends home institution itself was founded. All colleges in the study having Friends groups were founded prior to 1960; a surprisingly high percentage (52.1 percent) were in colleges established prior to 1900 . It is also notable that nine ( 40.9 percent) of the institutions currently having Friends groups are members of the prestigious Phi Beta Kappa. ${ }^{13}$ When institutions planning a Friends group are added to those that had a Friends group in the past, the Phi Beta Kappa percentage rises to 59 .

Total student enrollment was not a significant factor among libraries having Friends groups. It was noted, however, that 82.6 percent of those colleges having such groups have graduate programs, albeit some very small.

Profiles of those institutions having Friends groups in the tristate area indicate that neither a small collection nor relatively small professional staff size was a deterrent to their formation. Advanced institutional age, the existence of a graduate program, and Phi Beta Kappa membership, however, appear to favor the presence of a Friends group.

\section{Factors Affecting Formation of a Friends Group}

The most instrumental factor in initiating the Friends group was overwhelmingly the library director. In some cases the impetus for formation came at the suggestion of the president, the board of trustees, the library staff, alumni or their parents, the faculty, development officers, or even community members. The responsibility for forming the Friends group, however, invariably fell to the library director and his/her designees.

Factors stimulating interest in founding a Friends group were varied and complex. Most often cited was the perceived need to raise funds for items not covered by the 
budget or for a specific purpose (e.g., a building drive, equipment, special acquisitions). Enrichment of the collections and increasing the quality of the library were also frequently noted. Also recognized was the need for a library support and community outreach body. Public relations and fund-raising were often considered equally important.

Campus offices most often cited as helpful in forming the Friends group were president's, public relations, development, and alumni offices. Funding for an initial reception, help with mailing lists, press releases, printing, etc., represented the tangible assistance. Not all institutions, however, could rely on this type of help. In fact, many had little or no institutional support. Difficulties with development officers who saw the library's fundraising via Friends groups as impinging on their goals were cited. Others, who worked closely with development, however, spoke warmly of their support and guidance. The literature has shown how successful and effective the library can be in "bringing home the bacon" in college fund-raising efforts, ${ }^{14}$ so it is not unreasonable for the development office to cosponsor a Friends group.

The majority of respondents, when asked if they had consulted or been influenced by any other Friends group, replied that they had not; they had ventured alone into uncharted waters. However, the fact that six responding libraries named academic institutions, all within their city or county jurisdiction, suggests that libraries may take the lead from others nearby, communicating regularly via networks or area associations. Only one respondent cited being influenced by reading the professional literature; however, it is assumed that many respondents actually took this step.

\section{Description and Purpose of Groups}

The membership in the Friends groups in this study numbered anywhere from 35 to 400 . Sources of membership are varied: alumni, faculty, campus staff and officers, students, community residents, and businesses. Individuals beyond the campus find library circulation privileges an attrac- tive incentive to join.

Book sales, exhibits, book talks, lectures, etc., are frequently cited Friends activities. Meeting times vary from as few as one meeting per year to semiannual or even monthly gatherings. Friends publications (e.g., bulletins and facsimile editions) are an important activity, and frequently memorial donations are made.

The essential purpose of Friends groups is to provide programs that raise the visibility of the library. Thus, they stimulate interest in the library's collections and disseminate information about the library's needs as well as its strengths.

\section{"The socializing and good fellow- ship flowing from the Friends group help foster concern for the welfare and quality of the library."}

The socializing and good fellowship flowing from the Friends group help foster concern for the welfare and quality of the library. Friends are advocates for the library through membership drives, fundraising and enthusiastic publicity among their acquaintances and colleagues. The most significant achievements of Friends groups, as perceived by respondents, are building interest and good will, raising thousands of dollars for their institutions, purchasing equipment and furniture, and establishing endowments. Improved public relations for the library and the college itself are an additional benefit.

\section{Challenges Ahead}

All libraries acknowledged that successful Friends groups take a great deal of time and effort. The library director and designees must provide sustained guidance, communicating and reinforcing library goals and needs. The college administration's reception of Friends may range from enthusiasm to disinterest. Achieving administrative support, however, is helpful, if not necessary, to launching a successful group.

Friends groups struggle to maintain their momentum and membership. Ideas for workable programs that will attract 
and interest a wide audience must be actively sought and deadlines for publicity met. The group seeks to involve the membership broadly, so that a small loyal core is not doing all the work. Conflict can result when an insufficient number of Friends volunteer to work, and library staff are burdened with tasks such as secretarial support or assisting at sales. Broadening the membership will also help to counter the stereotypic image of Friends groups as gatherings of "little old ladies." In addition, active participation in the organization should be a source of pride and prestige, particularly for leadership positions.

The college's institutional fund-raising efforts were largely perceived as independent of the need for a library Friends group. One library reported, however, that their Friends were not permitted to mount a separate fund-raising effort. This conflict may also be seen in institutions with a collegewide Friends group; a library wishing to form an independent group may be viewed as acting at cross purposes with its institution's administrative thrust.

Library Friends' future goals consistently stressed membership recruitment and strengthening programs. Membership fees were being raised by some groups while others decried set or single-fee policies and were opting for categories of membership (e.g., student, sponsor, etc.). Many groups were attempting to tie fund-raising to specific purposes, such as computer equipment, building expansion, etc. Some groups were even exploring scheduling activities at various times to encourage increased attendance at programs. In this way they hope to develop a more vital organization and increase income.

\section{Recommendations}

Based on their experiences, respondents had several practical suggestions for beginning and operating a Friends group. The most fundamental suggestion was to define the purpose and goals of the group. Enlisting a broad membership and identifying volunteers was also suggested, in part by seeking out energetic, imagina- tive, sociable people with many acquaintances.

In terms of actual organization of the Friends group, contacting and obtaining the cooperation of as many campus offices as possible was advised. The goals of the Friends group should be clearly communicated and written agreements should be drawn up outlining specific assistance that had been offered. Such agreements, it was felt, could help avert future problems despite present cordial relations.

Good communication within the library was also stressed. Having a library staff liaison to the Friends was frequently suggested; and librarians were exhorted to keep the Friends informed of library needs and developments.

Administrators should pursue establishing a separate budget line for the Friends lest their income disappear into the college or university budget during exigencies. Library directors clearly preferred having control over use of Friends monies but if possible, if not, they at least wanted to provide advice or suggestions on how the money was spent. The flat membership fee issue was another matter of concern. Many groups were planning to discard the flat fee in lieu of membership categories.

Respondents urged those who would initiate a Friends group not to procrastinate. This call to action was perhaps best summed up in the terse suggestion of one library director, "Get started!"

\section{CONCLUSION}

This survey demonstrates that interest in college Friends is increasing. New groups are being organized, dormant groups revived, and many college libraries have begun to explore the possibility of initiating Friends groups.

Neither student enrollment, library volume count, nor professional staff size are significant factors in the existence of Friends groups. Institutional age, Phi Beta Kappa status, and the offering of master's level programs, however, are positive factors associated with the existence of Friends groups in the libraries surveyed.

The real test of the Friends group, how- 
ever, is the leadership and the need to have even one enthusiastic person willing to translate a vision into reality. Numerous examples were given in survey responses of "a person" who inspired others to share his or her dream of a Library Friends group and to work toward its implementation.
Initiating and operating Friends groups requires significant effort. For many, the commitment of time and energy was too great. For others, however, the monetary gains, good will, and fellowship Friends can generate was well worth the time and effort.

\section{REFERENCES AND NOTES}

1. Special Membership Committee, American Library Association, Friends of the Library Groups (Chicago: American Library Assn., 1937).

2. Sandy Dolnick, "Friends of Libraries U.S.A. Announce Survey Results," Directions 2:127 (Oct. 1986).

3. Computed from ". . . Respondents," Appendix 2, in Sandy Dolnick, ed., Friends of Libraries Sourcebook, (Chicago: American Library Assn., 1978).

4. The number of academic library Friends groups responding to the 1985 survey was verified on August 28, 1987, in a telephone conversation between Janet Butler Munch and Sandy Dolnick, executive director of Friends of Libraries U.S.A.

5. Esther H. Dixon, "Friends of College Libraries," ALA Bulletin 33:84-85 (1939).

6. M. Allyn Fox, "Friends of Library Groups in Colleges and Universities," College \& Research Libraries 12:353 (Oct. 1951).

7. Mother M. Fabian Carney, "Friends of Library Groups in Colleges and Universities," Catholic Library World 32:295 (Feb. 1961).

8. Ann Gwyn, Ann McArthur, and Karen Furlow, "Friends of the Library," College \& Research Libraries 36:272 (July 1975).

9. Sandy Dolnick, Friends of Libraries Sourcebook; and "Friends of Libraries U.S.A."

10. Sandy Dolnick, Friends of Libraries Sourcebook; Citizens Library Council of New York State, State University of New York at Albany, Friends of the Library: A Directory of Public/School/College and University/Special Library Friends Groups in New York State (New York: State Education Dept., New York State Library, 1982).

11. American Association of University Professors, "The Annual Report on the Economic Status of the Profession 1986-1987," Appendix I, Special Issue, Academe 73, no.2:46 (Mar./Apr. 1987).; "Carnegie Foundation's Classifications of Colleges," The Chronicle of Higher Education 33, no. 43:27 (July 8, 1987); College Division of Barron's Educational Services, Barron's Profiles of American Colleges Northeast, regional ed., 7th ed. (Woodbury, N.Y.: Barron's Educational Series, 1986).

12. Memo from Sandy Dolnick to Janet Butler Munch re: Friends of Library groups in tristate academic institutions, June 18, 1987.

13. Phi Beta Kappa, A Handbook for New Members 1985-1988 (Washington, D.C.: The United Chapters of Phi Beta Kappa, 1985).

14. "Research Libraries Turn More to Fundraising for Support," Library Journal 108:1632 (Sept. 1, 1983). 